\title{
Attitudes and intentions toward internet banking in an under developed financial sector
}

Kulondwa Safari, Aganze Bisimwa and Mugisho Buzera Armel Department of Financial Management, Universite Evangelique en Afrique, Bukavu, Congo (the Democratic Republic of the Congo)
Internet banking

\section{9}

Received 22 March 2020 Revised 14 August 2020 21 September 2020 Accepted 21 September 2020

\begin{abstract}
Purpose - The purpose of this study is to investigate customers' attitudes and intentions toward internet banking in an underdeveloped banking sector.

Design/methodology/approach - The study was carried out in the Democratic Republic of the Congo. A sample of 215 respondents comprised of 112 non-users and 103 users of internet banking was selected in the city of Bukavu following a convenience sampling method and structural equation modeling was applied to test the research hypotheses.

Findings - The results show that for users of internet banking their attitudes are determined by their perceived usefulness while for non-users they are determined by their perceived usefulness and internet trust. For users of internet banking, their intentions to continue using internet banking are determined by attitudes and perceived usefulness; while for internet banking non-users, their intention to use internet banking is determined by their attitudes, their perceived web security and perceived usefulness.

Originality/value - Few research on internet banking have been done in central and sub-Saharan Africa. The present study gives new insights to assist financial institutions and researchers in understanding intentions and attitudes toward internet banking in an underdeveloped financial sector.
\end{abstract}

Keywords Attitudes, Intentions, Fintech, Internet banking, SEM

Paper type Research paper

\section{Introduction}

Technology adoption is driving the social and economic interconnection in the world and it has become a significant factor of human progress (Patwardhan, 2017).

Traditional banking branches present many disadvantages that are being resolved by online banking. Internet banking is more than a simple way of delivering existing financial services and products. It can facilitate online payment and thereby entail the growth of electronic commerce. According to Jayawardhena and Foley (2000), internet banking offers other advantages that include the improvement of the bank reputation, cost savings and making the bank more interesting to new customers. It also attracts young customers, thus creating a higher competitiveness through new financial services offers (Polatoglu, 2003).

(C) Kulondwa Safari, Aganze Bisimwa and Mugisho Buzera Armel. Published in PSU Research Review. Published by Emerald Publishing Limited. This article is published under the Creative Commons Attribution (CC BY 4.0) licence. Anyone may reproduce, distribute, translate and create derivative works of this article (for both commercial and non-commercial purposes), subject to full attribution to the original publication and authors. The full terms of this licence may be seen at http:// creativecommons.org/licences/by/4.0/legalcode

This research has not received any funding.

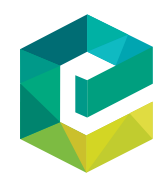

PSU Research Review Vol. 6 No. 1,2022 pp. $39-58$

Emerald Publishing Limited 2399-174 


\section{PRR}

6,1

Nowadays, financial services can be rendered through a variety of financial technologies, namely, cryptography, mobile wallets, roboadvisors, mobile apps, crowdfunding using Web 2.0 technology and many other technologies (Makina, 2019). Internet technology is helping to improve financial access and the usage of financial services (Fanta and Makina, 2019). Financial technology is creating a positive change in the way financial services are provided and new markets that motivate the unbanked to be included in the financial system (Makina, 2019).

Digital financial services offer many possibilities to include the unbanked in the financial system (Demirguc-Kunt et al, 2018). The increasing access to financial services can also help to reduce the level of poverty and to increase economic development (Owen and Pereira, 2018).

Financial technology is proven to have a positive impact on financial inclusion in emerging and advanced countries (Ozili, 2018) as technology is becoming a significant determinant of financial inclusion. Fanta and Makina (2019) posit that technology has the power to deliver financial services to people wherever they are and when they are needed.

Internet banking is well-documented to help expand access to financial services, reduce the costs of financial services and in offering services that meet customers' needs.

Digital channels are becoming noticeable everywhere and are being used significantly to deliver financial products. They have invented new ways to bring financial services to the unbanked for a reduced cost (Patwardhan, 2017).

The banking structure, regulations, consumer preferences are different among the countries despite the link between Fintechs around the world (London et al., 2018). The area of financial technology is changing very fast, and this change is reshaping the financial industry and the way financial services are provided (Xiao, 2018). There is a need for research on internet banking in underdeveloped regions among others Africa (Hanafizadeh et al, 2013).

\subsection{Internet banking in the democratic republic of the Congo}

The Democratic Republic of Congo is a post-conflict country and the largest country in subSaharan Africa. It is classified among underdeveloped countries (World Bank, 2018). It is considered by the International Monetary Fund as a financially underdeveloped country (Imf, 2014).The use of internet banking is still limited in the country. According to the Findex survey completed in 2017, in the Democratic Republic of the Congo, only 3\% of the labor force (15 years and more) have used the internet to pay bills; $3 \%$ to pay bills or to buy something online (percentage 15+) and 12\% made or received digital payments (World Bank, 2018). The Central Bank of Congo has shown that there is a need to increase the use of electronic financial transactions to extend financial inclusion and to improve the provision of financial services (Banque centrale du congo, 2018). Hence, this research aims to determine attitudes and intentions toward internet banking in the Democratic Republic of the Congo and to formulate recommendations for policymaking and strategies to expand the use of internet banking.

Many authors researched on different aspects of internet banking adoption among others Cheng et al. (2006), Eriksson and Nilsson (2004), Wang et al. (2006), Grabner-kra and Faullant (2008), Akinci et al. (2005), Gerrard et al. (2005), Kuisma et al. (2007); but none studied attitudes and intentions toward internet banking in an underdeveloped financial sector. The present study unlike others focuses on attitudes and intentions toward internet banking in an under developed financial sector specifically in the Democratic Republic of the Congo. Efforts are being done by the Central Bank of Congo to promote digital financial transactions, the present study will contribute to understand the attitudes and intentions of customers toward internet banking. This study uses secondary data from a survey on 215 individuals and an extended technology acceptance model (TAM) and structural equation modeling (SEM) are applied to get the results.

The paper proceeds as follows: In Section 2, we present a brief literature review. Section 3 focuses on the research methodology used to assess attitudes and intentions toward internet 
banking. Section 4 presents the findings from the analysis of the empirical data with the relevant discussion. Section 5 concludes the paper with the limitations of the study.

\section{Literature review}

This section defines internet banking and presents the TAM, as well as different empirical studies on the determinants of attitudes and intentions toward internet banking.

\subsection{Internet banking}

Methods of payment and management of finances are being revolutionized by digital advances. Nowadays, the usage of checks and cash for payments is being reduced and replaced by debits and credit cards, internet banking but also online shopping (Patwardhan, 2017). Internet banking is defined as the use of internet technology to provide traditional banking services to customers. The services include deposit and withdrawal transactions on a bank account, money transfets, as well as bill payment (Furst et al., 2000).

\subsection{Technology acceptance model}

TAM is considered as the ideal model to explain the user's intention to use a given technology. It has been widely used to determine the probability to adopt online technology. TAM is originally an information system theory that explains how technology is accepted and used. TAM has four important variables. These are, namely, perceived usefulness (PU), perceived ease of use (PEOU), behavioral intention (BI) and behavior (B). PU is used as both as a dependent and independent variable. It is dependent when it is predicted by perceived ease of use (PEOU) and it is independent when it predicts behavioral intention (BI) and actual behavior (B) (D and Davis, 1989; Davis, 2000).

Various studies have extended this model depending on the orientation of their studies. The following section presents several empirical studies, which extended this model for internet banking.

\subsection{Determinants of attitudes and intentions toward internet banking}

Various studies have used TAM variables to predict intentions to use internet banking and attitudes toward internet banking. Apart from the traditional TAM model, many empirical studies investigated the factors behind attitudes and intentions toward internet banking.

In relation to a given technology, intentions are defined as an individual's probability to perform a given behavior. Attitudes are defined as the user's assessment of the benefice of using the system. The theory of planned behavior shows that attitudes determine the intention to use or not a financial product (Ajzen, 1991). Lai and Li (2005) showed that customers' positive attitudes explain a positive intention to use internet technology. The study of Cheng et al. (2006) proved that positive attitudes toward internet banking have a direct impact on the intention to use internet banking. Therefore, in this study, it is proposed that:

H1: Customers' attitudes positively influence their intention to use Internet banking (IB) for non-users and for users.

The empirical literature indicates that attitudes toward internet banking and intentions to use internet banking are determined by the perceived usefulness (PU); perceived ease of use (PEU); perceived web security (PWS); internet trust (IT); and perceived risk of internet banking (PRIB).

2.3.1 Perceived usefulness. Perceived usefulness is the user's consideration that using a given system will improve the performance in conducting his work or transactions (Davis, 1989). The study of Eriksson and Nilsson(2004) demonstrated that perceived usefulness 
PRR

6,1

have a direct effect on actual use of internet banking while perceived ease of use have a direct effect on perceived usefulness and an indirect effect on the actual use of internet banking. The increase of the perceived usefulness of internet banking results in an increase of the intention to use it (Wang et al., 2006). Cheng et al. (2006) shows that perceived usefulness have a direct impact on attitudes. The customers with higher level of perceived usefulness of internet banking will have positive attitudes toward internet banking. Therefore, it is hypothesized that:

H2: Perceived usefulness has a positive effect on attitudes toward internet banking for users and non-users of internet banking.

H3: Perceived usefulness positively influences the intentions to use or to continue to use internet banking.

2.3.2 Perceived ease of use. Perceived ease of use is defined as the degree to which the user expects the system to be free of challenges in its utilization (D and Davis, 1989). The study of Lai and $\mathrm{Li}$ (2005) showed that perceived ease of use has a significant effect on the actual use of internet technology. Cheng et al. (2006) proved that perceived ease of use has a direct impact on attitudes toward internet banking. Users who consider internet banking as easy to use will have positive attitudes on it. According to TAM, perceived ease of use have a positive effect on perceived usefulness (Davis, 2000). Therefore, in this study, it is proposed that:

H4: Perceived ease of use has a positive effect on attitudes toward internet banking for users and non-users of internet banking.

H5: Perceived ease of use has a positive effect on perceived usefulness for users and non-users of internet banking.

2.3.3 Perceived web security. Perceived web security is considered as a key determinant of the intention to use internet technology and specifically internet banking. Sathye (1996) proved that security concerns and lack of awareness are the reasons for not adopting internet banking in Australia. The study of Cheng et al. (2006) showed that perceived web security have a direct effect on the intention to use internet banking. This study assumes that the lower the security of internet banking is perceived, the lower will be the intention to adopt it and the lower its perceived usefulness will be. Therefore, the following hypotheses are suggested:

H6: Perceived web security has a positive effect on Perceived usefulness for users and non-users of internet banking.

H7: Perceived web security positively influences the intention to use or to continue to use internet banking.

2.3.4 Internet trust. Trust is defined as a user's confidence in a given system reliability (Wang et al., 2006). Scholars have long been recognized that the behavior toward a technology is determined by the level of trust that individuals have in it. On the one hand, the study of Lai and Li (2005) showed that internet trust have a significant effect on the actual use of internet technology. According to the study of Suh and Han (2002), internet trust is the most important determinant of the intention to use internet banking. Trust have increases the intention to use internet banking (Wang et al., 2006). On the other hand, the study of Grabner-kra and Faullant (2008) proved that internet trust has a positive effect on attitudes toward internet banking. Customers with positive attitudes toward internet 
banking trust transactions that are conducted through the internet. Therefore, in this study, it is proposed that:

H8: Internet trust has a positive effect on attitudes toward internet banking.

H9: Internet trust has a positive effect on the perceived risk of internet banking.

2.3.5 Perceived risk of internet banking. Perceived risk is defined as an assessment of the level of danger or expected uncertainty in using a system or in making a purchase decision (Wang et al., 2006). The study of Grabner-kra and Faullant (2008) proved that the perceived risk of internet banking have a negative effect on attitudes toward internet banking. Many other studies came up with contrasted results showing that the perceived risk of internet banking affects positively attitudes toward it (Nasri, 2011; Boateng et al., 2016). Therefore, in this study, it is hypothesized that:

H10: Perceived risk of internet banking has a positive effect on attitudes toward internet banking.

\section{Research methodology}

\subsection{Data collection procedure}

The necessary data were derived from an online survey using Google forms. The survey questionnaires were sent out to individuals through mails and social media platform. This helped to reach out more respondents in a short time and at a minimum cost. The collection of data was conducted between 14th January and 15th February 2020. A sample of 215 respondents was selected randomly in Bukavu city among other 103 users of internet banking and 112 non-users. The data was processed using Smart PLS and statistical package for social sciences (SPSS) 21.

The sample included bank and microfinance institutions customers, users and non-users of internet banking. In total, $100 \%$ of our respondents have at least a high school level of education.

Referring to Grabner-kra and Faullant (2008), D and Davis (1989) and Cheng et al. (2006), we designed a survey questionnaire comprising three sections, namely, the first section included questions on respondents' demographic characteristics, the second section has questions on the use of internet banking and the last sections has items related to the TAM. All measurement items were drawn from existing prior literature, and they were adapted to fit within the context of the present study.

\subsection{Data analysis}

3.2.1 Empirical model. Many scholars including Alsajjan and Dennis (2010), Eriksson and Nilsson (2004); Lai and Li (2005), Suh and Han (2002); Wang et al. (2006) used TAM when analyzing the factors, which affect the adoption of a given financial technology or to assess attitudes toward financial technologies.

Based on prior literature, many variables are associated with attitudes toward financial technologies. However, these variables are not observed in isolation but they work in a certain interconnection. Therefore, it is useful to carry out a multi-variate analysis to get a better understanding of the full picture.

Referring to Cheng et al. (2006), Alsajjan and Dennis (2010), Grabner-kra and Faullant (2008), Shih (2004), Eriksson and Nilsson (2004), Suh and Han (2002), Wang et al. (2006), this study used SEM to explain attitudes and intentions toward internet banking. 
PRR

6,1

During the past years, behavioral finance researchers have increased their interest in the application of SEM. Historically, the research areas where multi-variate techniques have been used were the behavioral and biological sciences. Nowadays, interest in multi-variate methods have expanded to many other fields of research among others business and finance (Alvin, 1995).

SEM is a concept used to describe a growing and increasingly general set of statistical methods for modeling data. The biggest strength of SEM is its capacity to model links between latent variables; these are unobserved constructs of which observed variables may be for them misrepresentative.

3.2.2 Empirical model formulation and measurement. This section presents the mathematical formulation of our model and the path diagram.

The dependent variables for our models are attitudes and intentions. TAM constructs and extended TAM constructs constituted our independent variables. All our variables are measured by items with Likert scale. The measurement of items used in this study was derived and adapted from the studies of Cheng et al. (2006), Akinci et al. (2005) and Grabnerkra and Faullant (2008). The dependent and independent variables used in the model are described in Table 1 the model formulation is presented below:

$$
\begin{gathered}
A T T=T A M \beta_{i}+e_{i} \\
I N T=T A M \beta_{1 i}+A T T \beta_{2 i}+e_{i}
\end{gathered}
$$

3.2.3 Path diagram. Figures 1 and 2 below represent the relationships between our latent

\begin{tabular}{|c|c|c|c|}
\hline Variable & Description & Measurement & Nature \\
\hline $\begin{array}{l}\text { Attitudes } \\
\text { (ATT) }\end{array}$ & $\begin{array}{l}\text { This variable measures the user's } \\
\text { assessment of the benefice of using internet } \\
\text { banking }\end{array}$ & Ordinal, Likert scale items & Dependent \\
\hline Intention (INT) & $\begin{array}{l}\text { This variable measures an individual's } \\
\text { probability to use internet banking }\end{array}$ & Ordinal, Likert scale items & Dependent \\
\hline $\begin{array}{l}\text { IT (internet } \\
\text { trust) }\end{array}$ & $\begin{array}{l}\text { This variable measures user's confidence in } \\
\text { the internet reliability }\end{array}$ & Ordinal, Likert scale items & Independent \\
\hline $\begin{array}{l}\text { PEU (perceived } \\
\text { ease of use) }\end{array}$ & $\begin{array}{l}\text { Perceived ease of use assesses the degree to } \\
\text { which internet banking users and non-users } \\
\text { consider or expect the system to be free of } \\
\text { challenges in its utilization }\end{array}$ & Ordinal, Likert scale items & Independent \\
\hline $\begin{array}{l}\mathrm{PU} \text { (perceived } \\
\text { usefulness) }\end{array}$ & $\begin{array}{l}\text { Perceived usefulness is the user's } \\
\text { consideration that using a given system will } \\
\text { improve the performance in conducting his } \\
\text { work or transactions }\end{array}$ & Ordinal, Likert scale items & Independent \\
\hline $\begin{array}{l}\text { PWS (perceived } \\
\text { web security) }\end{array}$ & $\begin{array}{l}\text { Perceived web security measures the } \\
\text { consideration toward security of the web } \\
\text { operations and specifically internet banking }\end{array}$ & Ordinal, Likert scale items & Independent \\
\hline $\begin{array}{l}\text { PRIB } \\
\text { (perceived risk } \\
\text { of internet } \\
\text { banking) }\end{array}$ & $\begin{array}{l}\text { Perceived risk is defined as an assessment } \\
\text { of the level of danger or expected } \\
\text { uncertainty in using internet banking }\end{array}$ & Ordinal, Likert scale items & Independent \\
\hline
\end{tabular}
variables based on our hypothesis (Figures 3).

Table 1.

Variables descriptions variables based on our hypothesis (Figures 3 ). 


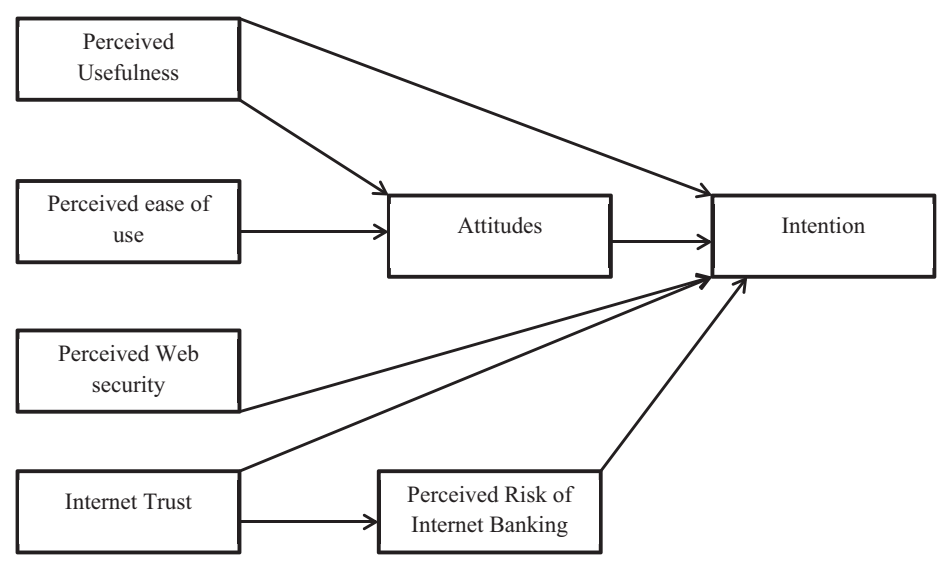

Figure 1. Research framework

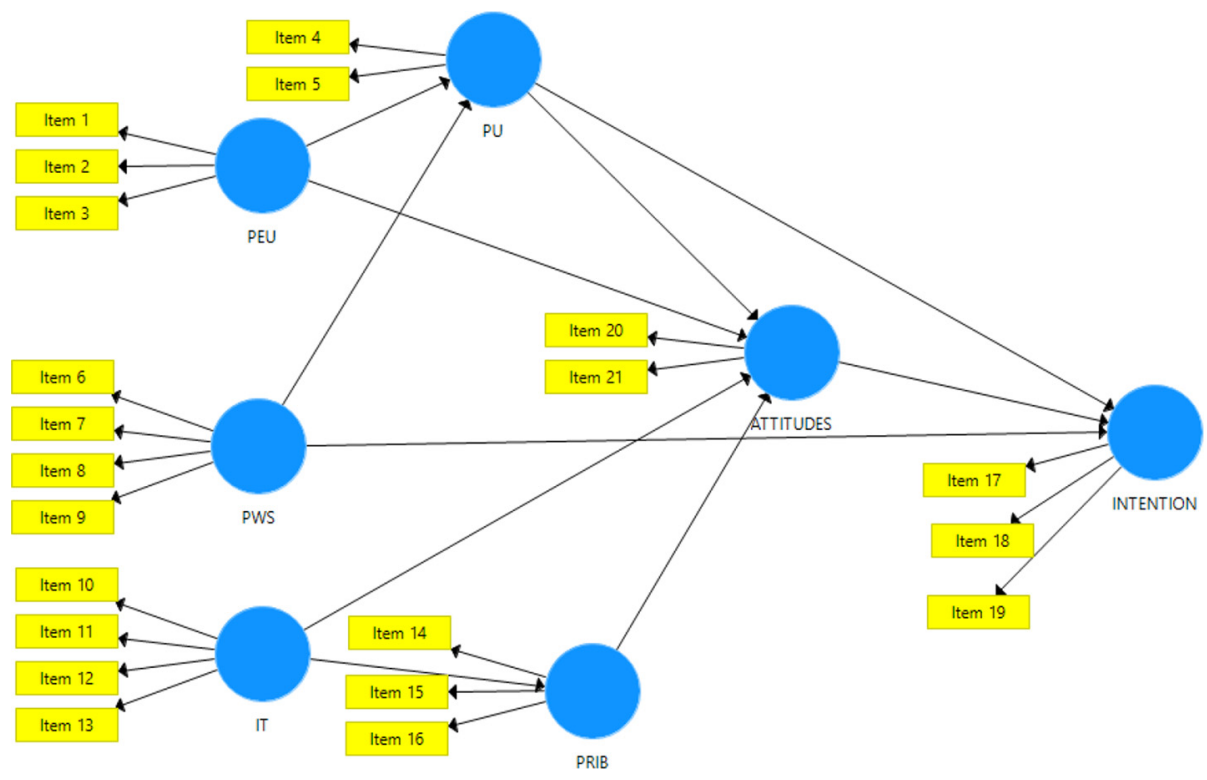

Figure 2.

Path diagram for users of internet banking

\section{Results}

This section presents the characteristics of our respondents and the study results from the SEM.

\subsection{Characteristics of users of internet banking}

The results in Table 2 show that most of the respondents using internet banking were male $92.2 \%$ this result is in line with the study of (Akinci et al., 2005), which proved that most of the users of internet banking are male. However, in Table 3, most of the respondents not using internet banking are also found to be male $81.3 \%$. 
PRR

6,1

46

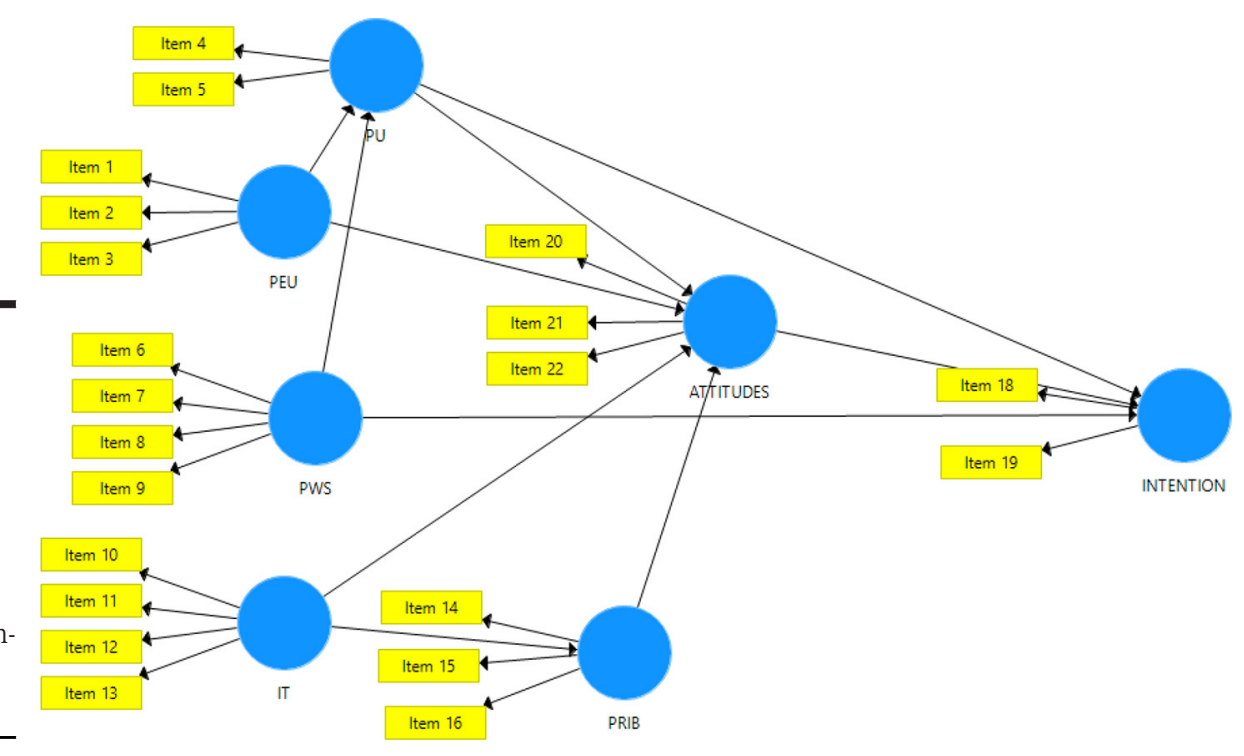

Figure 3.

Path diagram for nonusers of internet banking

\begin{tabular}{lrr}
\hline Profile & Frequency & $(\%)$ \\
\hline Sex & & \\
Female & 8 & 7.8 \\
Male & 55 & 92.2 \\
Total & 103 & 100.0 \\
Age & & \\
$18-25$ & 14 & 13.6 \\
$26-30$ & 48 & 46.6 \\
$31-45$ & 35 & 34.0 \\
$46-60$ & 3 & 2.9 \\
61 and above & 3 & 2.9 \\
Total & 103 & 100.0 \\
Employment & & \\
Employed & 63 & 61.2 \\
Student & 7 & 6.8 \\
Unemployed & 33 & 100.0 \\
Total & 103 & \\
Easy access to internet & & 26.2 \\
No & 27 & 100.0 \\
Yes & 76 & \\
Total & 103 & 35.0 \\
Problems using internet banking & & 65.0 \\
No & 36 & 100.0 \\
Yes & 67 & \\
Total & 112 & \\
& & \\
& & \\
& &
\end{tabular}

Table 2.

Profile of users of internet banking
Yes 


\begin{tabular}{|c|c|c|c|}
\hline Demographic profile & Frequency & $(\%)$ & $\begin{array}{l}\text { Internet } \\
\text { banking }\end{array}$ \\
\hline $\begin{array}{l}\text { Sex } \\
\text { Female } \\
\text { Male } \\
\text { Total }\end{array}$ & $\begin{array}{r}21 \\
91 \\
112\end{array}$ & $\begin{array}{r}18.8 \\
81.3 \\
100.0\end{array}$ & \\
\hline $\begin{array}{l}\text { Age } \\
18-25 \\
26-30 \\
31-45 \\
46-60 \\
\text { Total }\end{array}$ & $\begin{array}{r}21 \\
49 \\
35 \\
7 \\
112\end{array}$ & $\begin{array}{r}18.8 \\
43.8 \\
31.3 \\
6.3 \\
100.0\end{array}$ & 47 \\
\hline $\begin{array}{l}\text { Employment } \\
\text { Employed } \\
\text { Student } \\
\text { Unemployed } \\
\text { Total }\end{array}$ & $\begin{array}{r}63 \\
14 \\
35 \\
112\end{array}$ & $\begin{array}{r}56.3 \\
12.5 \\
31.3 \\
100.0\end{array}$ & \\
\hline $\begin{array}{l}\text { Easy access to internet } \\
\text { No } \\
\text { Yes } \\
\text { Total }\end{array}$ & $\begin{array}{r}35 \\
77 \\
112\end{array}$ & $\begin{array}{r}31.3 \\
68.8 \\
100.0\end{array}$ & \\
\hline $\begin{array}{l}\text { Own account in a bank or mfi } \\
\text { No } \\
\text { Yes } \\
\text { Total }\end{array}$ & $\begin{array}{r}28 \\
84 \\
112\end{array}$ & $\begin{array}{r}25.0 \\
75.0 \\
100.0\end{array}$ & $\begin{array}{r}\text { Table } 3 . \\
\text { Profile of non-users } \\
\text { of internet banking }\end{array}$ \\
\hline
\end{tabular}

According to the results in Table 2, most of users of internet banking have the age between 26 and 30 years, however people aged between 46 and 60 years and above were found to be few among users. These results are in line with the study of Mattila (2003), which proved that mature people of more than 60 years are late adopters of internet banking. Akinci et al. (2005) has also emphasized that internet banking users are mid-aged. The findings in Table 3 show that most of non-users of internet banking are between 26 and 30 years of age. These results are not in line with the study of Akinci et al. (2005) that showed that most of non-users of internet banking are older.

The majority of our respondents using internet banking are employed $63 \%$ (Table 2). We also surveyed unemployed people and students because they are also expected to conduct financial transactions. In Table 3 , the majority of non-users are employed (56.3\%). These are potential users of internet banking.

In Table 2, most of the users of internet banking interviewed $(76 \%)$ acknowledged having easy access to the internet. In Table 3, the majority of nonusers also have easy access to the internet $(77 \%)$. These results show that access to the internet is not a major player in not using internet banking. In Table 2, the majority of internet banking users $(67 \%)$ declared experiencing problems when using internet banking.

Results in Table 3 show that the majority of internet banking non-users (75\%) have access to financial services through a bank or microfinance institution. These are potential subscribers to internet banking. 


\section{PRR}

6,1

48

\subsection{Structural equation modeling results}

This section presents the internal consistency and reliability tests, the convergent and discriminant validity, the correlations, the estimated structural equations, the predictive power test and the goodness of fit test.

4.2.1 Internal consistency and reliability tests. In this study, we used Chronbach's alpha completed by composite reliability to test the consistency reliability of our constructs. Cronbach's alpha is the lower border of internal consistency reliability and the composite reliability is the upper border. A good construct's internal consistency reliability is between 0.60 and 0.70 . The Minimum acceptable is 0.70 and 0.60 for an exploratory research (Risher, 2018).

After the first estimations of our structural equations, for the internet banking user's model, we have removed internet trust and for non-users model, we have removed perceived risk of internet banking for not passing the reliability test. The results from the second estimations are presented below (Figures 4 to 7 ).

The results in Figure 3 show that for internet banking users' model the Cronbach's alpha for our interests variables are above 0.7 except for perceived usefulness and attitudes. However, the analysis of the composite reliability (Figure 5) show that all the constructs are reliable with an index above 0.6 except for attitudes, which is between 0.5 and 0.55 but we kept it in the final model because it is a dependent variable. In Figure 4, the results for the internet banking non-users model indicate that the Cronbach's alpha for our significant variables is above 0.7 except attitudes, which is also close to 0.7 . For the internet banking non-users model, the analysis of the composite reliability (Figure 6) for all the constructs are above 0.6 , and therefore, all the constructs are reliable (Figure 7).

4.2.2 Convergent validity, discriminant validity and correlations. Convergent validity and discriminant validity should be used to evaluate the measurement model (Hair et al., 2012). Individual reliability is assessed by the outer loadings of each item for each construct.

Figure 4.

Cronbach's alpha for internet banking users' model

\section{Cronbach's Alpha}

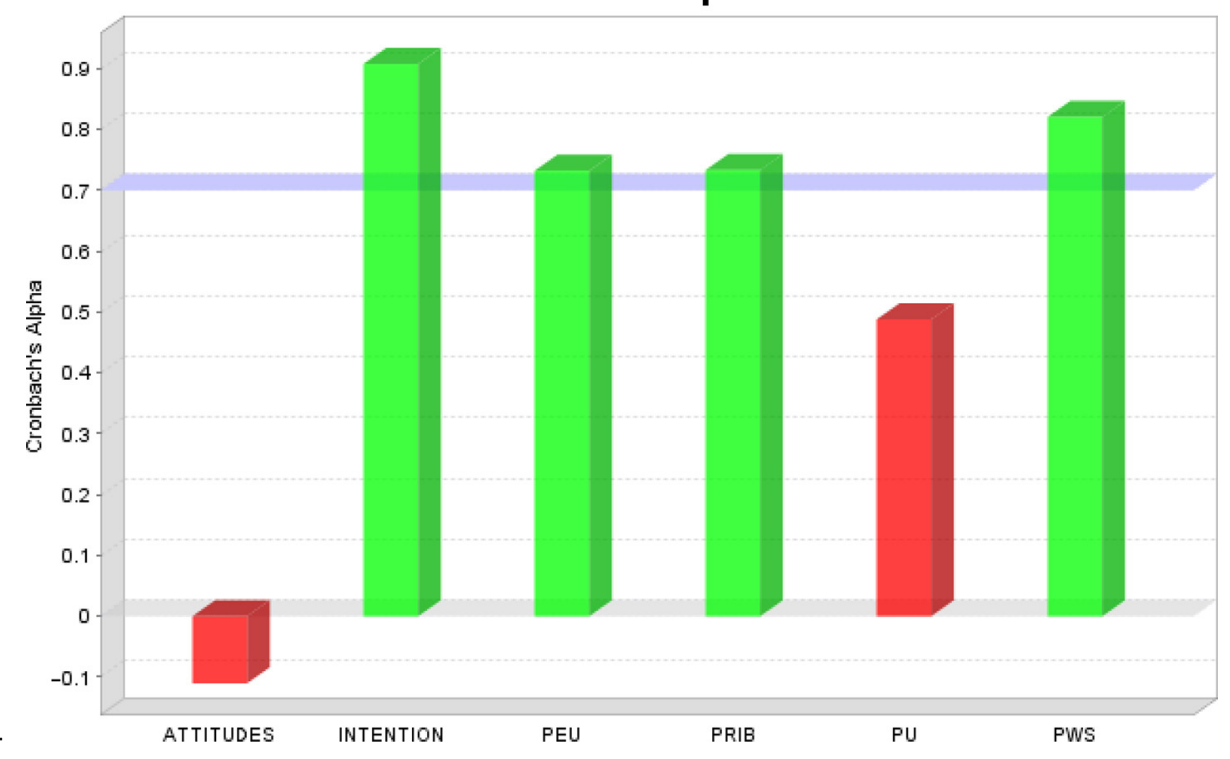




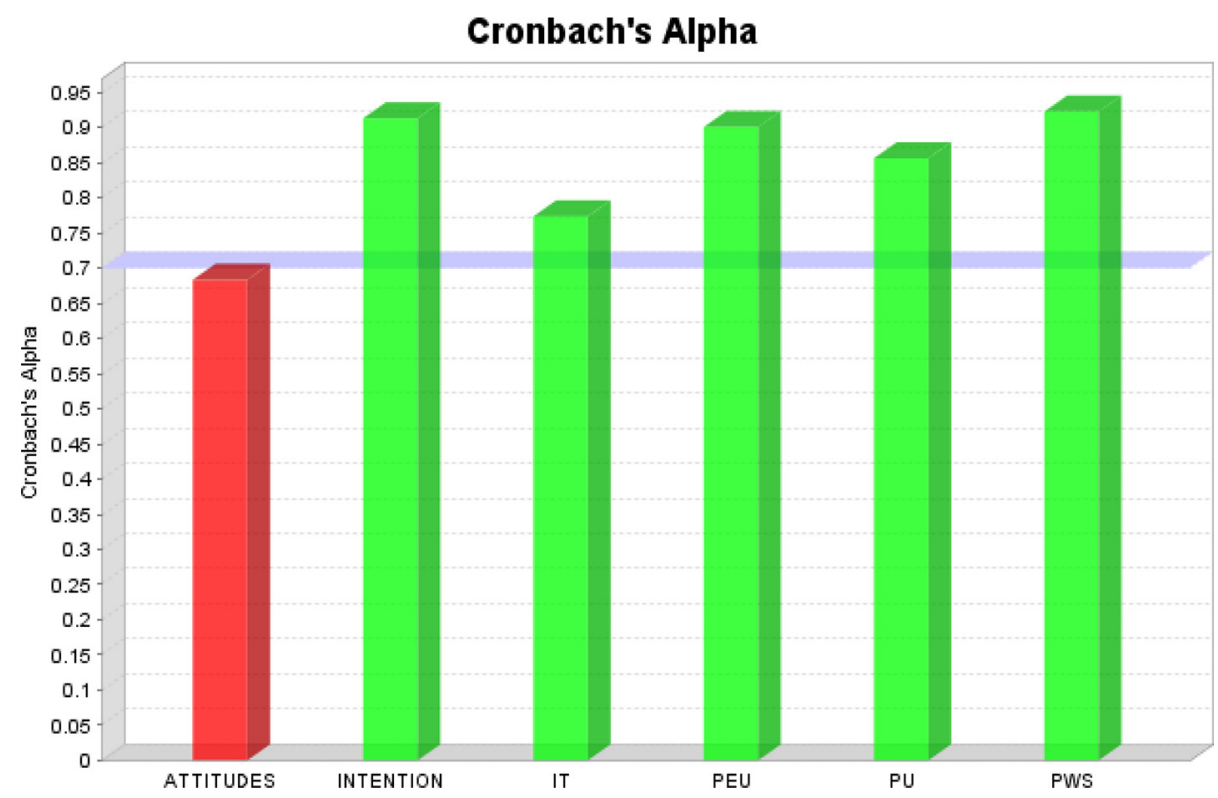

Internet

banking

Figure 5.

Cronbach's alpha for internet banking nonusers model

\section{Composite Reliability}

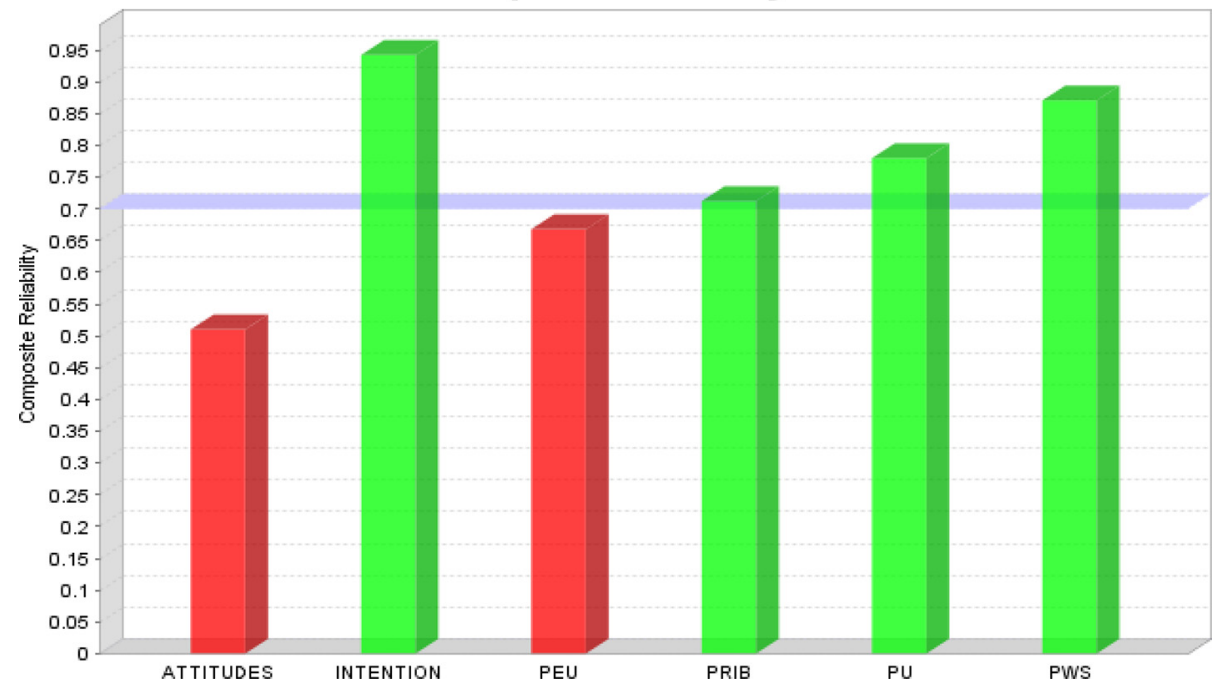

Figure 6. Composite reliability for internet banking user's model

The outer loading should be between 0.40 and 0.70 or above 0.70 for the item to be retained (Hair et al., 2012; Lee and Goh, 2019). The discriminant validity was assessed following Fornell-Larcker criterion (Fornell and Larcker, 2016). As threshold, Fornell and Larcker (2016) suggested to use AVE (average variance extracted) with the minimum of 0.50 or the AVE should be higher than the correlations among the latent variables. 
PRR

6,1

50

Figure 7.

Composite reliability for internet banking non-users model

\section{Composite Reliability}

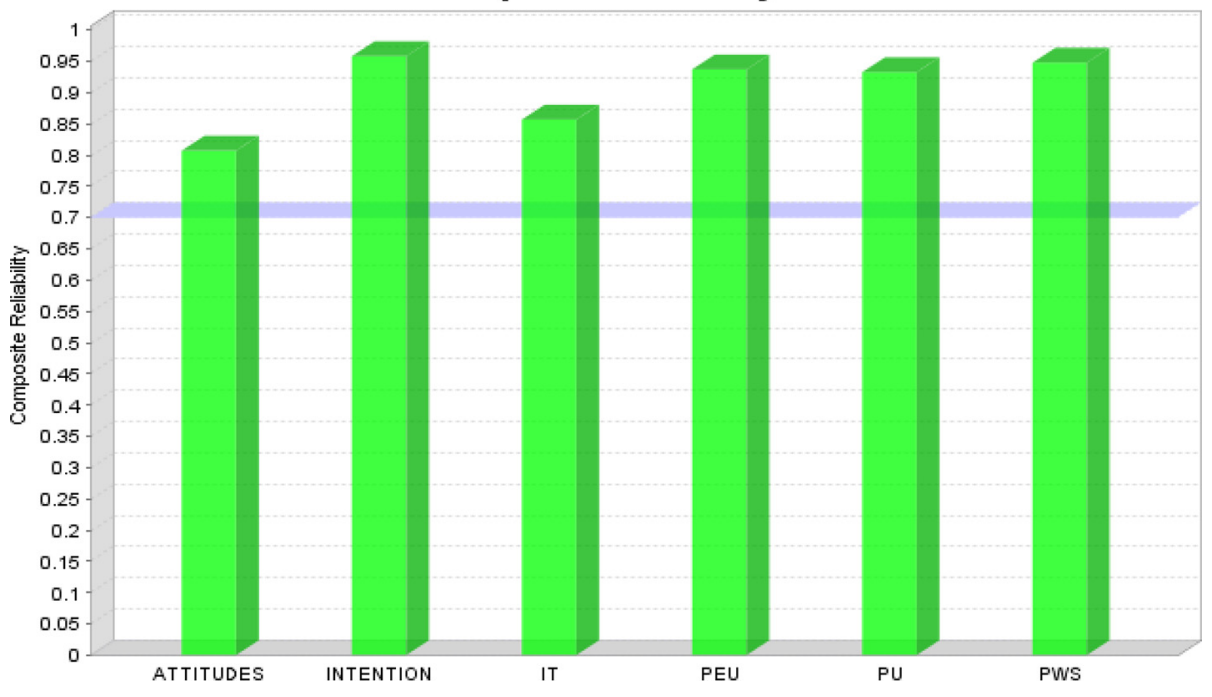

The results in Tables 4 and 6 show that, all the items outer loadings are in the range between 0.40 and 0.70 or above 0.70 the study met, therefore, individual item reliability criterion. As displayed in Tables 5 and 7, all square roots of AVE (diagonal values) are above 0.5 and are more than the correlation coefficients between the constructs (off-diagonal values) suggesting that discriminant validity is adequate. The convergent validity of these constructs is thus, considered as adequate. Most of the correlations between independent latent variables displayed in Tables 5 and 7 are low, this shows that there is no risk of multicollinearity (Tables 4 to 7 ).

\begin{tabular}{|c|c|c|c|c|c|c|}
\hline Items & Attitudes & Intention & IT & PEU & $\mathrm{PU}$ & PWS \\
\hline Item 1 & & & & 0.934 & & \\
\hline Item 10 & & & 0.602 & & & \\
\hline Item 11 & & & 0.850 & & & \\
\hline Item 12 & & & 0.772 & & & \\
\hline Item 13 & & & 0.858 & & & \\
\hline Item 18 & & 0.959 & & & & \\
\hline Item 19 & & 0.960 & & & & \\
\hline Item 2 & & & & 0.912 & & \\
\hline Item 20 & 0.866 & & & & & \\
\hline Item 21 & 0.482 & & & & & \\
\hline Item 22 & 0.900 & & & & & \\
\hline Item 3 & & & & 0.892 & & \\
\hline Item 4 & & & & & 0.930 & \\
\hline Item 5 & & & & & 0.940 & \\
\hline Item 6 & & & & & & 0.696 \\
\hline Item 7 & & & & & & 0.969 \\
\hline Item 8 & & & & & & 0.965 \\
\hline Item 9 & & & & & & 0.966 \\
\hline
\end{tabular}


4.2.3 Estimated structural equations using bootstrapping. In this study, we have analyzed only the direct effect between our latent variables. The results in Table 8 show that four positive relationships in our structural equation are significant with a $p$-value below 0.05 (5\%). H1-H3 and $H 6$ are, therefore, confirmed. These are positive relationships between

\begin{tabular}{lcrrrrr}
\hline Variables & Attitudes & Intention & IT & PEU & PU & PWS \\
\hline Attitudes & 0.773 & & & & & \\
Intention & 0.756 & 0.959 & & & & \\
IT & 0.694 & 0.668 & 0.777 & & & \\
PEU & 0.318 & -0.037 & 0.396 & 0.913 & & \\
PU & 0.696 & 0.385 & 0.774 & 0.415 & 0.935 & \\
PWS & 0.698 & 0.708 & 0.723 & 0.109 & 0.596 & 0.907
\end{tabular}

Note: Values on the diagonal represent the square root of the AVE, while the off-diagonals represent correlations

Table 5.

Discriminant validity

(Fornell-Larcker criterion), correlations, average variance extracted for non-users model

\begin{tabular}{|c|c|c|c|c|c|c|c|}
\hline Items & Attitudes & Intention & PEU & PRIB & PU & PWS & \\
\hline Item 1 & & & 0.536 & & & & \\
\hline Item 14 & & & & 0.493 & & & \\
\hline Item 15 & & & & 0.990 & & & \\
\hline Item 16 & & & & 0.651 & & & \\
\hline Item 17 & & 0.933 & & & & & \\
\hline Item 18 & & 0.885 & & & & & \\
\hline Item 19 & & 0.939 & & & & & \\
\hline Item 2 & & & 0.427 & & & & \\
\hline Item 20 & 0.997 & & & & & & \\
\hline Item 21 & 0.427 & & & & & & \\
\hline Item 3 & & & 0.969 & & & & \\
\hline Item 4 & & & & & 0.663 & & \\
\hline Item 5 & & & & & 0.922 & & \\
\hline Item 6 & & & & & & 0.841 & \\
\hline Item 7 & & & & & & 0.863 & Table 6. \\
\hline Item 8 & & & & & & 0.595 & Factor loading values \\
\hline Item 9 & & & & & & 0.851 & for user's model \\
\hline
\end{tabular}

\begin{tabular}{lcccccr}
\hline Variables & Attitudes & Intention & PEU & PRIB & PU & PWS \\
\hline Attitudes & 0.705 & & & & & \\
Intention & 0.701 & 0.919 & & & & \\
PEU & 0.214 & 0.145 & 0.667 & & & \\
PRIB & 0.356 & 0.312 & 0.545 & 0.705 & & \\
PU & 0.530 & 0.712 & 0.068 & 0.293 & 0.803 & \\
PWS & 0.484 & 0.480 & 0.349 & 0.167 & 0.364 & 0.795
\end{tabular}

Note: Values on the diagonal represent the square root of the AVE, while the off-diagonals represent correlations

Table 7.

Table discriminant validity (FornellLarcker criterion), correlations, average variance extracted for user's model 
PRR

6,1

52

Table 8.

Estimated structural equation for internet banking users
Attitudes and intention, perceived usefulness and attitudes, perceived usefulness and intention, perceived web security and perceived usefulness. Hence, attitudes toward internet banking for users in the Democratic Republic of the Congo is determined by its perceived usefulness while the intention to continue using the internet banking is determined by the attitudes, and its perceived usefulness. These results are in line with the findings of Lai and Li (2005), Cheng et al. (2006), Eriksson and Nilsson (2004). In the context of Africa, these results are contrasted with the findings from the study of Nasri (2011) in Tunisia who showed that perceived risk and perceived security are the factors behind the intention to use internet banking. In Ghana, Boateng et al. (2016) found out that trust influence intentions to adopt internet banking. However, the study also supported that perceived ease of use does not have an effect on the intention to adopt internet banking. In the same country, Kwateng et al. (2011), supported that trust and perceived security are significant determinant of continuation to use internet banking.

The results in Table 9 above show that six positive relationships in our structural equation are significant with a $p$-value below $0.05(5 \%) . H 1-H 3$ and $H 5-H 8$ are confirmed by the results. These are the positive relationships between customers' attitude and intention, perceived usefulness and attitudes, perceived usefulness and intentions to use internet banking, perceived ease of use and perceived usefulness, perceived web security and perceived usefulness, perceived web security and the intention to use the internet

\begin{tabular}{lccccc}
\hline Variables & $\begin{array}{c}\text { Original } \\
\text { sample }(\mathrm{O})\end{array}$ & $\begin{array}{c}\text { Sample } \\
\text { mean }(\mathrm{M})\end{array}$ & $\begin{array}{c}\text { Standard deviation } \\
(\mathrm{STDEV})\end{array}$ & $\begin{array}{c}T \text {-statistics } \\
(|\mathrm{O} / \mathrm{STDEV}|)\end{array}$ & $p$-values \\
\hline Attitudes $\rightarrow$ Intention & 0.640 & 0.609 & 0.070 & 9.097 & $\mathbf{0 . 0 0 0}$ \\
$\mathrm{PEU} \rightarrow$ attitudes & 0.090 & -0.035 & 0.131 & 0.687 & 0.492 \\
$\mathrm{PEU} \rightarrow \mathrm{PU}$ & -0.067 & 0.151 & 0.157 & 0.427 & 0.669 \\
$\mathrm{PRIB} \rightarrow$ attitudes & 0.168 & 0.148 & 0.138 & 1.219 & 0.223 \\
$P U \rightarrow$ attitudes & 0.474 & 0.480 & 0.062 & 7.609 & $\mathbf{0 . 0 0 0}$ \\
$P U \rightarrow$ intention & 0.359 & 0.369 & 0.058 & 6.199 & $\mathbf{0 . 0 0 0}$ \\
$\mathrm{PWS} \rightarrow$ intention & 0.040 & 0.052 & 0.045 & 0.873 & 0.383 \\
$P W S \rightarrow P U$ & 0.387 & 0.399 & 0.075 & 5.175 & $\mathbf{0 . 0 0 0}$
\end{tabular}

Note: Significant values at $5 \%$ level of significance are in bold italics
Table 9.

Estimated structural equation for internet banking non-users

\begin{tabular}{lccccc}
\hline & $\begin{array}{c}\text { Original } \\
\text { sample } \\
(\mathrm{O})\end{array}$ & $\begin{array}{c}\text { Sample } \\
\text { mean }(\mathrm{M})\end{array}$ & $\begin{array}{c}\text { Standard deviation } \\
(\mathrm{STDEV})\end{array}$ & $\begin{array}{c}T \text {-statistics } \\
(|\mathrm{O} / \mathrm{STDEV}|)\end{array}$ & $p$-values \\
Variables & 0.711 & 0.716 & 0.065 & 10.961 & $\mathbf{0 . 0 0 0}$ \\
Attitudes $\rightarrow$ intention & 0.381 & 0.399 & 0.143 & 2.659 & $\mathbf{0 . 0 0 8}$ \\
$I T \rightarrow$ attitudes & 0.005 & -0.030 & 0.129 & 0.039 & 0.969 \\
$\mathrm{PEU} \rightarrow$ attitudes & 0.354 & 0.366 & 0.052 & 6.859 & $\mathbf{0 . 0 0 0}$ \\
$P E U \rightarrow P U$ & 0.391 & 0.380 & 0.140 & 2.784 & $\mathbf{0 . 0 0 6}$ \\
$P U \rightarrow$ attitudes & -0.366 & -0.361 & 0.055 & 6.628 & $\mathbf{0 . 0 0 0}$ \\
$P U \rightarrow$ intention & 0.430 & 0.411 & 0.071 & 6.056 & $\mathbf{0 . 0 0 0}$ \\
$P W S \rightarrow$ intention & 0.557 & 0.557 & 0.060 & 9.343 & $\mathbf{0 . 0 0 0}$ \\
$P W S \rightarrow P U$ & & & & &
\end{tabular}

Note: Significant values at $5 \%$ level of significance are in bold italics 
banking, internet trust and attitudes. Therefore, attitudes toward internet banking for nonusers in the Democratic Republic of the Congo are determined by the perceived usefulness, internet trust while the intention to use internet banking is determined by the attitudes, the perceived web security and the perceived usefulness. These results confirmed partially the findings of Wang et al. (2006) and Cheng et al. (2006). Using a sample of bank customers in advanced developing countries, Akinci et al. (2005), showed that non-users of internet banking do not have intentions to adopt it because they think they could not get help in case they experience problems while using it. This study demonstrated that perceive ease of use was the main determinant of the intentions to use internet banking (Figures 8 and 9).

4.2.4 Predictive power tests. For internet banking user's model, the results in Table 10 indicate a high explanatory model for intention, meaning that $81.7 \%$ of changes in intentions toward internet banking for users is explained by the significant variables in our model while only $33 \%$ of changes in attitudes is explained by the model (this is a moderate explanatory power).

For internet banking non-users model, the results for $R^{2}$ analysis in Table 11 indicate a high explanatory model for intentions. In total, $70.2 \%$ of change in intentions toward internet banking for non-users is explained by the estimated model and $53.8 \%$ of changes in attitudes are explained by the significant variables in our model.

4.2.5 Model fit test. Referring to Haron and Aziz (2019), we have used the good of fitness index (Gof) to test the fitness of our estimated model. The GoF index is bound between 0 and 1 , whereby the model with a higher fit is the better or more valid model. The GoF value of 0.10 is considered as small while GoF value of 0.25 and 0.36 is considered as medium and large, respectively.

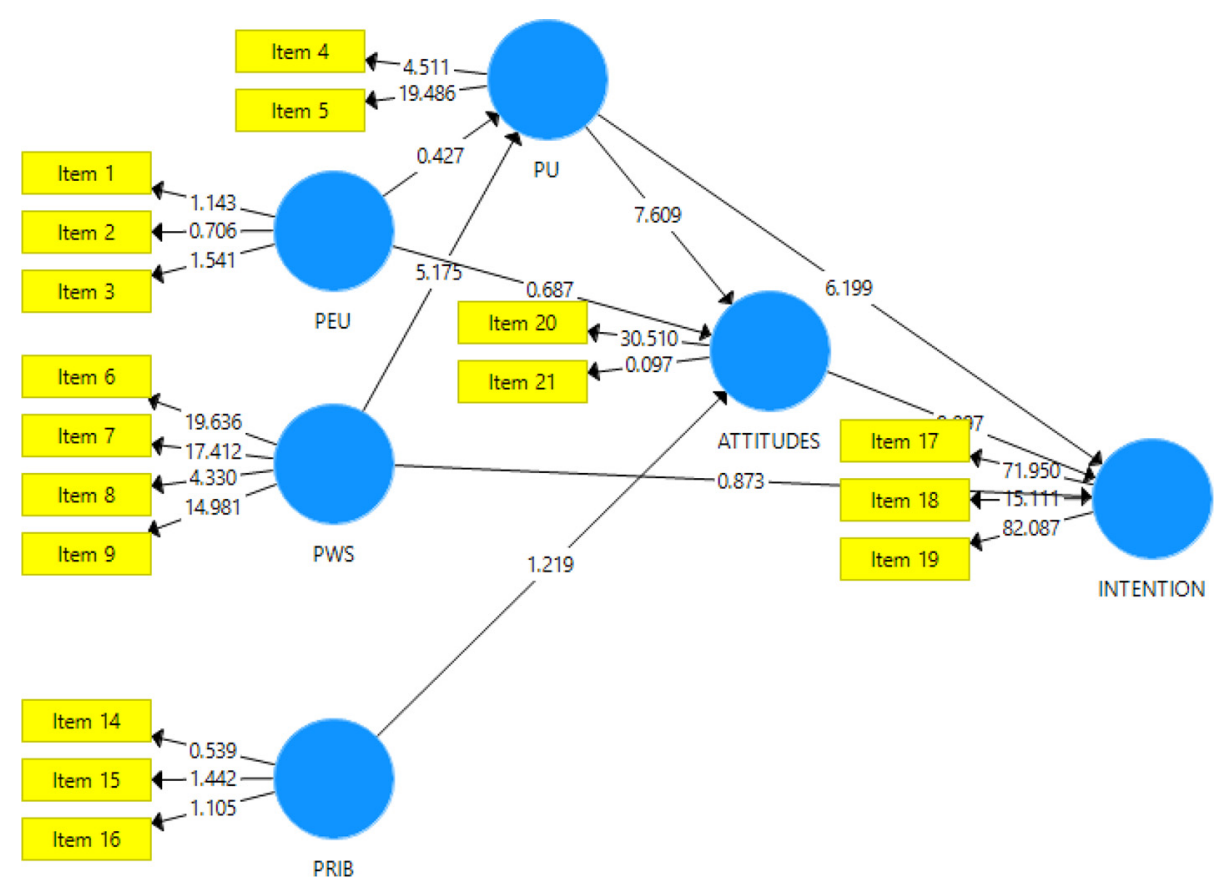

Figure 8. Diagram of the estimated model for users of internet banking 


\section{PRR}

6,1

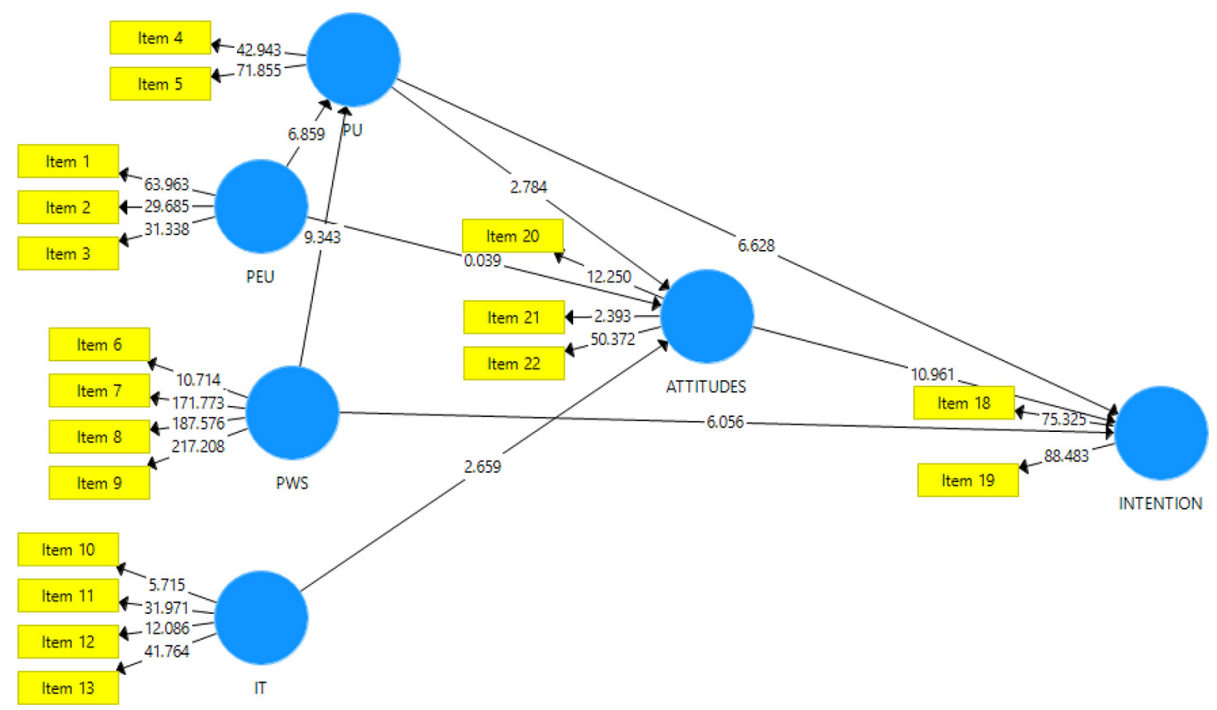

Table 10.

Predictive power of the estimated model for users of internet banking

\begin{tabular}{lcc}
\hline Variables & $R^{2}$ & $R^{2}$ adjusted \\
\hline Attitudes & 0.330 & 0.310 \\
Intention & 0.817 & 0.812 \\
PU & 0.136 & 0.119 \\
\hline
\end{tabular}

Table 11.

Predictive power of the estimated model for non-users of internet banking

\begin{tabular}{lcc}
\hline Variables & $R^{2}$ & $R^{2}$ adjusted \\
\hline Attitudes & 0.538 & 0.525 \\
Intention & 0.702 & 0.694 \\
PU & 0.479 & 0.469 \\
\hline
\end{tabular}

For the internet banking user's model, our estimated model generated a GoF value of 0.503 (Table 12), which proved that the model has a better fitting. For non-users of the internet banking model, the results for the Gof index in Table 13 (0.669392262) indicate a good fit for our estimated model.

\section{Conclusion}

Technology was proved to play a key role in improving the quality of financial services (Fanta and Makina, 2019). This research investigated attitudes and intentions toward internet banking in the Democratic Republic of Congo, which is a financially underdeveloped country and where the rate of financial inclusion is still low. This research 
responds to the need of empirical research on internet banking in underdeveloped regions as emphasized by Hanafizadeh et al. (2013).

After internal consistency tests and discriminant test, we estimated the structural equations that tested our hypotheses. Our final models were proved to have a good prediction and fitting power after performing, respectively, the $R^{2}$ and goodness of fit index tests.

In the one hand, our results revealed that for users of internet banking in the Democratic Republic of the Congo especially the city of Bukavu, their positive attitudes toward internet banking is determined by an increase in perceived usefulness while for non-users their positive attitudes toward the internet banking is determined by an increase in the perceived usefulness and internet trust.

On the other hand, positive intentions to continue using internet banking are determined by positive attitudes and an increase in perceived usefulness; while the intention to use internet banking for non-users is determined by the positive attitudes toward it, the perceived web security and the perceived usefulness. Comparatively to previous research, the findings from this study challenge findings from previous studies in confirming some of them and contrasting others. The theory of planned behavior showing that attitudes influence intentions are confirmed.

Therefore, there is a need to increase awareness on the usefulness and safety of internet banking with the purpose to boost the use of this financial technology innovation in financially underdeveloped countries. In general, the findings from this study could help policymakers in financially underdeveloped countries to adapt their internet banking services to attitudes and intentions of customers. This study is key in the context of the

\begin{tabular}{lcrr}
\hline Constructs & Average variance extracted (AVE) & \multicolumn{1}{c}{$R^{2}$} \\
\hline Attitudes & 0.497 & 0.330 \\
Intentions & 0.845 & 0.817 & \\
PRIB & 0.497 & 0.136 & \\
PU & 0.444 & & Table 12. \\
PEU & 0.645 & 0.427666667 & Good of fitness test \\
PWS & 0.633 & & for users of internet \\
Average score & 0.5935 & & banking \\
Average* $\left.R^{2} * R^{2}\right)^{1 / 2}$ & 0.253820167 & & \\
GoF $=(\mathrm{AVE} * 3805683$ & 0.50380 & & \\
\hline
\end{tabular}

\begin{tabular}{|c|c|c|c|}
\hline Constructs & Average variance extracted (AVE) & $R^{2}$ & \\
\hline Attitudes & 0.597 & 0.538 & \\
\hline Intentions & 0.920 & 0.702 & \\
\hline $\mathrm{PU}$ & 0.874 & 0.479 & \\
\hline IT & 0.604 & & \\
\hline PU & 0.874 & & \\
\hline PWS & 0.823 & & Table 13. \\
\hline Average score & 0.782 & 0.573 & Model fit test for non- \\
\hline Average* $R^{2}$ & 0.448086 & & users of internet \\
\hline $\mathrm{GoF}=\left(\mathrm{AVE} * R^{2}\right)^{1 / 2}$ & 0.669392262 & & banking \\
\hline
\end{tabular}


PRR

6,1

Democratic Republic of Congo where the Central Bank has made the improvement of digital financial services a priority.

Further studies need to be carried out with a bigger sample and including more provinces across the country. The moderating effect of financial literacy on internet banking usage needs also to be verified.

\section{References}

Ajzen, I. (1991), "The theory of planned behavior", Organizational Behavior and Human Decision Processes, Vol. 50 No. 2, pp. 179-211.

Akinci, S., Aksoy, S. and Atilgan, E. (2005), "Adoption of internet banking among sophisticated consumer segments in an advanced developing country”, doi: 10.1108/02652320410530322.

Alsajjan, B. and Dennis, C. (2010), "Internet banking acceptance model: cross-market examination", Journal of Business Research, Vol. 63 Nos 9/10, pp. 957-963, doi: 10.1016/j.jbusres.2008.12.014.

Alvin, C.R. (1995), Methods of Multivariate Analysis, John willey and sons.

Banque centrale du congo (2018), "Rapport Annuel",

Boateng, H., Adam, D.R., Okoe, A.F. and Anning-Dorson, T. (2016), "Computers in human behavior assessing the determinants of internet banking adoption intentions: a social cognitive theory perspective”, Computers in Human Behavior, Vol. 65, pp. 468-478, doi: 10.1016/j.chb.2016.09.017.

Cheng, T.C.E., Lam, D.Y.C. and Yeung, A.C.L. (2006), "Adoption of internet banking: an empirical study in Hong Kong”, Decision Support Systems, Vol. 42 No. 3, pp. 1558-1572, doi: 10.1016/j.dss.2006.01.002.

Davis, F.D. (1989), "Perceived usefulness, perceived ease of use, and user acceptance of", Mis Quarterly, Vol. 13 No. 3, pp. 319-340.

Davis, F.D. (2000), "A theoretical extension of the technology acceptance model: four longitudinal field studies a theoretical extension of the technology acceptance model: Four longitudinal field studies', (February)", doi: 10.1287/mnsc.46.2.186.11926.

Demirguc-Kunt, A., Klapper, L., Singer, D., Ansar, S. and Hess, J. (2018), "The global findex database 2017", Measuring Financial Inclusion and the Fintech Revolution. The World Bank, doi: 10.1596/ 978-1-4648-1259-0.

Eriksson, K. and Nilsson, D. (2004), "Customer acceptance of internet banking in Estonia', (1998)", International Journal of Bank Marketing, Vol. 23 No. 2, doi: 10.1108/02652320510584412.

Fanta, A.B. and Makina, D. (2019), "10 - The relationship between technology and financial inclusion: Cross-Sectional evidence", Extending Financial Inclusion in Africa, doi: 10.1016/B978-0-12814164-9.00010-4.

Fornell, C. and Larcker, D.F. (2016), "Evaluating structural equation models with unobservable variables and measurement”, Vol. 18 No. 1, pp. 39-50.

Furst, K., Lang, W.W. and Nolle, D.E. (2000), “Internet banking: developments and prospects', (September)”,

Gerrard, P., et al. (2005), "International journal of bank marketing emerald article: the diffusion of internet banking among Singapore consumers the diffusion of internet banking among Singapore consumers”, doi: 10.1108/02652320310457776.

Grabner-Kra, S. and Faullant, R. (2008), "Consumer acceptance of internet banking: the influence of internet trust”, International Journal of Bank Marketing, Vol. 26 No. 7, pp. 483-504, doi: 10.1108/ 02652320810913855

Hair, J.F., et al. (2012), "An assessment of the use of partial least squares structural equation modeling in marketing research", Journal of the Academy of Marketing Science, Vol. 40 No. 3, pp. 414-433, doi: 10.1007/s11747-011-0261-6.

Hanafizadeh, P., Keating, B.W. and Reza, H. (2013), "Telematics and informatics a systematic review of internet banking adoption”, Telematics and Informatics, Vol. 31 No. 3, doi: 10.1016/j.tele.2013.04.003. 
Haron, R. and Aziz, S. (2019), "Predicting small and medium-sized adoption of financial technology in Islamic Crowd-Funding”, doi: 10.4018/978-1-7998-0039-2.ch002. (September)

$\operatorname{Imf}$ (2014), "Democratic republic of the Congo financial system stability assessment", Vol. 14, pp. 0-61.

Jayawardhena, C. and Foley, P. (2000), "Changes in the banking sector \pm the case of internet banking in the UK", Vol. 10 No. 1.

Kuisma, T., Laukkanen, T. and Hiltunen, M. (2007), "Mapping the reasons for resistance to internet banking: a means-end approach”, International Journal of Information Management, Vol. 27 No. 2, pp. 75-85, doi: 10.1016/j.ijinfomgt.2006.08.006.

Kwateng, K.O., Afo, K. and Atiemo, O. (2011), 'Acceptance and Use of Mobile Banking: An Application of UTAUT2, doi: 10.1108/JEIM-03-2018-0055.

Lai, V.S. and Li, H. (2005), “Technology acceptance model for internet banking: an invariance analysis", Information and Management, Vol. 42 No. 2, pp. 373-386, doi: 10.1016/j.im.2004.01.007.

Lee, J.E. and Goh, M.L. (2019), "Understanding purchase intention of university students towards skin care products", PSU Research Review, Vol. 3 No. 3, pp. 161-178, doi: 10.1108/PRR-11-2018-0031.

London, W., et al. (2018), "Fintech in a global setting", pp. 269-283, doi: 10.1016/B978-0-12-8134979.00014-7.

Makina, D. (2019), The Potential of Fintech in, Extending Financial Inclusion in Africa, Elsevier Inc. doi: 10.1016/B978-0-12-814164-9.00014-1.

Mattila, M. (2003), "Internet banking adoption among mature customers: early majority or laggards?”, Journal of Services Marketing, Vol. 17 No. 5, pp. 514-528, doi: 10.1108/08876040310486294.

Nasri, W. (2011), "Factors influencing the adoption of internet banking in Tunisia", Vol. 6 No. 8, pp. 143-160, doi: 10.5539/ijbm.v6n8p143.

Owen, A.L. and Pereira, J.M. (2018), "Bank concentration, competition, and financial inclusion”, Review of Development Finance, Vol. 8 No. 1, pp. 1-17, doi: 10.1016/j.rdf.2018.05.001.

Ozili, P.K. (2018), "Borsa _ Istanbul review impact of digital finance on financial inclusion and stability”, Borsa Istanbul Review, Vol. 18 No. 4, pp. 329-340, doi: 10.1016/j.bir.2017.12.003.

Patwardhan, A. (2017), Financial Inclusion in the Digital Age. 1st Edn, Handbook of Blockchain, Digital Finance, and Inclusion, Volume 1: Cryptocurrency, Fin Tech, InsurTech, and Regulation, 1st edn. Elsevier Inc. doi: 10.1016/B978-0-12-810441-5.00004-X.

Polatoglu, V.N. (2003), "An empirical investigation of the turkish consumers 'acceptance of internet banking services",

Risher, J. (2018), "When to use and how to report the results of PLS-SEM", European Business Review, Vol. 31 No. 1, doi: 10.1108/EBR-11-2018-0203 (April 2019).

Sathye, M. (1996), “Adoption of internet banking by australian consumers: an empirical investigation”,

Shih, Y. (2004), "The use of a decomposed theory of planned behavior to study internet banking in Taiwan”, Internet Research, Vol. 14 No. 3, pp. 213-223, doi: 10.1108/10662240410542643.

Suh, B. and Han, I. (2002), "Effect of trust on customer acceptance of internet banking", Vol. 1, pp. 247-263.

Wang, Y.S., Wang, Y.M., Lin, H.H. and Tang, T.I. (2006), "Determinants of user acceptance of internet banking: an empirical study", doi: 10.1108/09564230310500192.

World Bank (2018), "Democratic republic of Congo systematic country diagnostic policy priorities for poverty reduction and shared prosperity in a post-conflict country and fragile state", Report No. 112733-ZR, (112733).

Xiao, Y.Q.J. (2018), "Fintech: AI powers financial services to improve people’ s lives".

\section{Corresponding author}

Kulondwa Safari can be contacted at:kulsaf2@gmail.com or kulsaf@uea.ac.cd 


\section{Appendix. Survey questionnaire}

6,1

\section{Questionnaire}

I. Demographic characteristics

1. Employment status: Employed Unemployed Student

2. Sex: Male Female

3. Age: $18-25 \quad 26-30 \quad 31-45 \quad 46-60 \quad>60$

II. Question on internet banking use

1. I have easy access to the Internet: No yes

2. I use internet banking for my transactions: Yes No

$\checkmark$ I encounter problem frequently when using Internet banking

$\checkmark$ I use internet banking service frequently to get information on my account

III. ITEMS

\section{Perceived Ease of Use}

(1) Using the Internet Banking service is easy for me

(2) I find my interaction with the use of Internet Banking services clear and understandable

(3) It is easy for me to become skillful at the use of Internet Banking services

Perceived Usefulness

(4) Using the Internet Banking would enable me to accomplish my tasks more quickly

(5) I would find the Internet Banking useful

Perceived Web Security

(6) I would feel secure sending sensitive information across Internet Banking

(7) The Internet Banking is a secure means through which to send sensitive information

(8) I would feel totally safe providing sensitive information about myself over the Internet Banking

(9) Overall, the Internet Banking is a safe place to transmit sensitive information

Internet trust:

(10)With adequate safety measures on a web site I do not hesitate to enter my credit card information

(11) I trust the internet

(12)When performing a transaction on the internet I know exactly what will happen

(13) Internet transactions (e.g. online shopping or online hotel reservations)always function as expected

Perceived risk of internet banking:

(14) I am afraid that other people might get access to information about my internet banking transactions.

(15) I believe it can rather easily happen that money is stolen if using internet banking.

(16) I think that privacy is not guaranteed when using internet banking.

Intention to Use

(17) I will continue to use internet banking (only for users)

(18) I would use the Internet Banking for my banking needs.

(19) Using the Internet Banking for handling my banking transactions is something I would do

Attitudes

(20) Using Internet Banking is a good idea

(21) I would feel that using Internet Banking is pleasant

(22) In my opinion, it would be desirable to use Internet Banking (only for non-users) 